\title{
Diaspora Remittances and Stock Market Development at Nairobi Securities Exchange, Kenya
}

\author{
Cliff Osoro ${ }^{1} \quad$ Eddie Simiyu $\mathrm{PhD}^{2} \quad$ Job Omagwa $\mathrm{PhD}^{2}$ \\ 1.PhD Student, Kenyatta University, School of Business, P O Box 43844-00100 Nairobi, Kenya \\ 2.Kenyatta University, School of Business, P O Box 43844-00100 Nairobi, Kenya
}

\begin{abstract}
Diaspora remittances, unlike other external sources of financing, tend to be more stable making remittances a reliable source of financing for emerging economies. Despite the consistent upward trend in diaspora remittances, emerging capital markets are typically characterized by a small number of listing and very high volatility. This study therefore sought to establish the effect of diaspora remittances on stock market development at the Nairobi Securities Exchange, Kenya. The study covered the period 2008-2018 and quarterly time series data was analysed using correlation analysis and the Autoregressive Distributed Lag Model. The study findings document a significant positive effect of diaspora remittances on stock market development in the short run as evidenced by the negative and significant coefficient of the Error Correction Term (ECT). Equally, diaspora remittances had a significant positive effect on stock market development in the long run. In view of the foregoing findings, the study recommends that the Kenya government should create a department of economic relations located at all Kenyan foreign embassies abroad to educate Kenyans abroad on the available investment opportunities at the Nairobi Securities Exchange and the importance of investing back at home.
\end{abstract}

Keywords: Diaspora Remittances, Political Risk, Foreign Investor Participation, Stock Market Development and Nairobi Securities Exchange (NSE).

DOI: $10.7176 /$ RJFA/11-6-12

Publication date:March $31^{\text {st }} 2020$

\section{Introduction and Background}

The Kenyan economic blue print of vision 2030 aims at transforming the country into a newly industrialized middle income country that provides high quality life to its citizens. Moreover, the vision 2030 envisions an efficient and transparent stock market. This huge milestone is to be achieved through the deepening of the financial markets by expanding the bond, equity markets and leveraging on remittances and other long term foreign capital inflows (Republic of Kenya, 2007). Notably, the Nairobi Securities Exchange is however characterized by very small size and high volatility. The growth in the number of listed firms and the market liquidity is very low with the market turnover averaging at less than 10 percent of the overall market capitalization. The annual trend in key equity market indicators at the Nairobi Securities Exchange market for the period 2008-2018 are summarized in Table.1.

Table 1: Key Equity Market Indicators (2008-2018)

\begin{tabular}{|l|l|l|l|l|l|l|l|l|l|l|l|}
\hline Market indicato & $\mathbf{2 0 0 8}$ & $\mathbf{2 0 0 9}$ & $\mathbf{2 0 1 0}$ & $\mathbf{2 0 1 1}$ & $\mathbf{2 0 1 2}$ & $\mathbf{2 0 1 3}$ & $\mathbf{2 0 1 4}$ & $\mathbf{2 0 1 5}$ & $\mathbf{2 0 1 6}$ & $\mathbf{2 0 1 7}$ & $\mathbf{2 0 1 8}$ \\
\hline $\begin{array}{l}\text { Market } \\
\text { capitalization (Bn }\end{array}$ & 853.8 & 834.17 & 1167 & 868.2 & 1272 & 1920 & 2316 & 2054 & 1931 & 2521.8 & 2102 \\
\hline $\begin{array}{l}\text { Equity Turno } \\
\text { (Bn) }\end{array}$ & 97.52 & 38.16 & 110.3 & 78.06 & 86.79 & 115.8 & 215.7 & 209.4 & 147.2 & 171.6 & 175.6 \\
\hline NSE 20 Share Ind & 3521 & 3247 & 4432 & 3205 & 4133 & 4927 & 5113 & 4041 & 3186 & 3732 & 2834 \\
\hline Listed Firms & 55 & 55 & 55 & 58 & 61 & 61 & 64 & 64 & 66 & 67 & 67 \\
\hline
\end{tabular}

Source: CMA quarterly statistical bulletins (2008-2018)

Table 1 indicates that Market capitalization declined from Kshs. 853.1 Billion in 2008 to Kshs. 834.1 Billion in the year 2009 representing a loss of Kshs. 20 Billion while market turnover declined sharply from Kshs. 97.52 Billion to Kshs. 38.16 Billion over the same period. This can be attributed to the lagged aftermath effects of the global financial crisis and the post-election violence as foreign investors moved away their investments from the domestic market (Kibaara, 2008). The market recovered from the effects of the global financial crisis and the postelection violence in the year 2010 experiencing a steady bullish run till 2015 when the market capitalization decelerated from Kshs.2,316 Billion in the year 2014 to Kshs.2,054 Billion in the year 2015 representing a loss of Kshs. 262 Billion in a single financial year (CMA, 2016). The decline can be attributed to the re-introduction of the capital gains tax by the treasury that led to massive capital outflow and the subsequent replacement with a one off transaction fee of $0.3 \%$ on the value of the transaction (Gachanja \& Kosimbei, 2018). The market capitalization picked a growth momentum in the year 2016-2017. However the worst decline throughout the period was experienced in the year 2018 attributed to the aftermath effects of the prolonged election period of 2017-2018. During this period the market capitalization dropped by over Kshs.400 Billion from Kshs. 2521 Billion in 2017 to Kshs. 2102 Billion in 2018 (NSE, 2018). The Market liquidity was very low throughout the period with market 
turnover increasing marginally from Kshs. 97.52 Billion in 2007 to Kshs. 175 Billion in 2018 (CMA, 2018).

Diaspora Remittances include all the monetary transfers that are received by the residents from the nonresidents and also include the compensation given to resident employees working abroad for short periods that are usually less than a year (IMF, 2005). Diaspora remittances are not only became important source of revenue to any country but are also a very important source of income to its residents and families for consumption (Bayar, 2016). However, not all the diaspora remittances are consumed; but rather part of the consumption of remittances is delayed through savings and investment. Unlike other sources of external finance, diaspora remittances tend to be more stable making remittances a reliable source of financing for developing countries (Ratha \& Mohapatra, 2007). This is attributed to the fact remittances are directly sent to the recipient from the sender and are therefore not subject to the government bureaucratic bottlenecks affecting other foreign financial inflows such as foreign direct investment.

Stock market development is the process through which the stock market increases in size, liquidity, price stability, linkage with other markets, and variety of instruments, improved technology and market concentration (Wassal, 2013). From the foregoing stock market development is therefore a multi-faceted, long-term and complex process that is measured by several factors. However, recent studies conducted globally and in the emerging markets of Sub-Saharan Africa indicate that a lot of emphasis has been placed on Market capitalization ignoring other indicators of stock market development (Oziengbe \& Ovuefyen, 2013; Soumare \& Tchana, 2011; Idenyi et al., 2016; Mohanty, 2016; Raza \& Jawaid, 2014 and Nyangoro,2013). This can be attributed to the fact that foreign financial flows into and out of the domestic market leads to increased fluctuation in the value of stocks and liquidity of the market. Market size is measured using the number of listed firms or the value of market capitalization (Nwiado \& Deekor, 2013). Market capitalization is however preferred due to its direct relationship with the firms' ability to mobilize capital and its future growth prospects (Rajan \& Zangles, 2003). Moreover, market capitalization and liquidity are able to capture the high frequency changes in the stock market. In view of the foregoing the study measured stock market development using market capitalization, market turnover and NSE All Share index.

\section{Problem Statement}

Despite the stock markets' pivotal role towards economic growth, stock market development in Kenya and its contribution to economic growth is still an issue of great concern (Republic of Kenya, 2016). Emerging capital markets are typically characterized by a small number of listing, high volatility, lack sophisticated infrastructure and have a narrow range of tradable instruments (Hearn \& Pearse, 2006). According to Nyangoro (2013), the Nairobi Securities Exchange market is characterized by small size and very low liquidity. Further, the stock market demonstrates significant structural and regulatory weaknesses (Ngugi, Amanja \& Amana, 2013). During the study period 2008-2018, the NSE 20 share index moved from 4843 basis points in the first quarter of the year 2008 to 3521.18 points by the end of the fourth quarter of 2008 and further dropped to 3247.44 points by the end of 2009 . This decline is far below the NSE 20 share index psychological mark of 4000 basis points. In 2010 the index registered steady increase to 4432.6 points but further declined to 3224.18 points in the year 2011.The index increased steadily to reach 5212.11 basis points in 2014 but further declined to 4040.75 in 2015 . The index further registered an increase to 3186 points before increasing by 17\% to close at 3712 points in 2017 (NSE, 2017). However the worst decline is registered in the year 2018 when the market index declined by $24 \%$ to close the year at 2834 points (NSE, 2018). Moreover, the liquidity of the NSE is very low throughout the period 2008-2018 with market turnover increasing marginally from a minimum value of Kshs. 97.52 Billion in 2008 to a maximum value of Kshs. 175 Billion in 2018 (CMA, 2018). Despite the substantial returns generated in emerging markets, the cyclical nature of the markets makes it impossible for the existing and potential investors to accurately predict market returns. Excessive volatility affects the smooth operations of the market and consequently the reduce returns on investment (Barnor, 2014).

Worth noting, unlike other foreign financial inflows that fluctuate with uncertainty in the political environment, diaspora remittances demonstrate a consistent upward trend over the years. Diaspora remittances from developed economies have increased rapidly in recent years even exceeding the amount of foreign direct investment in most developing countries (Raza \& Jawaid, 2012). Diaspora remittances have become such an important source of foreign capital inflows to the developing countries and its contribution towards stock market development cannot be under estimated. The amount of remittances invested in the stock market largely depending on the returns generated from other money market instrument (Kalim \& Shahbaz, 2013). Whenever the returns generated from other money market instrument is low relative to stock market returns, diaspora remittances can be directed to the stock market through the purchase of equity instruments in listed companies. According to Njoroge (2014), increased awareness by the Kenyans in the diaspora on the availability of investment opportunities and the high returns in the stocks market has led to increased amount of remittances investment in the Nairobi Securities Exchange market. This has the effect of increasing stock market size, liquidity and price stability hence leading to development of the market. Despite the wavering trends on the development of the NSE, there remains 
little empirical evidence on the effect of diaspora remittances on stock market development in Kenya. Hence, the study sought to establish the effect of Diaspora remittances on Stock market development at NSE, Kenya. Equally, in view of the foregoing the study measured stock market development using market capitalization as a proxy of market size, market turnover as a proxy of market liquidity and NSE All Share index as a measure of market volatility.

\section{Literature Review}

These sections provide a review of relevant theories that support the relationship between diaspora remittance and development of stock markets. Hence, the following theories were applied to explain the study relationship: Pure Self- Interest Theory and Base Broadening Theory. These theories are discussed in detail in this section.

The Pure Self Interest Theory was triggered by Lukas and Stark (1985). According to the Pure Self Interest Theory an emigrant sends remittances with the aspiration to inherit or makes investments for the future with the intention to return home in future and derive benefits from such investments. Emigrants send money home because they expect to return home and can expect to receive family gratitude for having sent remittance (Vargas \& Huang, 2006). The main goal of remitting income from the foreign country to the domestic country is for investments that are expected to earn returns in future when the remitter eventually come back at home. Thus remittances act as a strategy of investment for future returns (Docquier \& Rappoport, 2005). Such investments are placed under the care of family members who serve as care takers or agents acting on behalf of the diaspora emigrant. The Kenyan government through the foreign investment policy takes note of the immense contribution and untapped potential of the Kenyan living in the diaspora (Republic of Kenya, 2014). The diaspora diplomacy pillar aims at tapping into the skills, knowledge, expertise and resources of the Kenyans in the diaspora to facilitate their integration into the national development agenda.

The Base Broadening theory was proposed by Merton (1987). The theory contends that expanding the number of investors, through the liberalization of the financial markets, to include investors from foreign countries would lead to increased diversification. Increased diversification leads to lower risk and consequently lowering the required risk premium. This has the effect of increasing capital availability in the stock market, liquidity and price stability hence leading to development of the stock market (Galindo et al., 2007). The liberalization of the financial markets, leads to increased market efficiency and better allocation of resources to the most optimum users in the domestic capital markets (Yartey \& Adjasi, 2008). According to the theory, the assumed factors barring foreigners' investments from holding fully diversified portfolios are informational in that; investors will fail to invest in stocks if they are not fully informed about the returns available in the capital markets. Therefore according to Base Broadening theory, if both the domestic and foreign investors from the diaspora share the same information sets they will invest equivalently (Merton, 1987).

Empirical studies conducted on the relationship between diaspora remittances and stock market development have either focused on either long term or short term effects of remittances on stock market development in isolation. This creates the need to test both the long run and short run dynamics simultaneously using a lagged model such as the Autoregressive Distributed Lag model (ARDL). Secondly, the studies have equally taken a restricted view that stock market development is measured using a single indicator (Njoroge, 2014; Raza \& Jawaid, 2014; Githaiga \& Kabiru, 2014). However of importance to note stock market development is a multi-faceted complex process that is measured using various indicators. These studies are further discussed in greater detail below.

Njoroge (2014), sought to determine the effect of Diaspora remittances on stock market performance using evidence from the Nairobi Securities Exchange. Stock market performance was measured by The Nairobi Securities Exchange All Share Price Index (NASI). Inflation, interest rates and exchange rates were used as control variables. Time series monthly data for seven years from February 2008-May 2015 was obtained from the Nairobi Securities Exchange and the Kenya Central Bank was used for the purpose of meeting the study objectives. The study applied both descriptive analysis and multiple regression analysis. The study findings indicated that Diaspora remittance had strong and significant positive effect on stock market performance. The current study however analyses the relationship between diaspora remittances and stock market development using autoregressive distributed lag model.

Raza and Jawaid (2014) studied the effect of remittances on stock market development in 18 Asian countries. The study covered the period 2000-2010 and time series data was analyzed using ARDL cointergration and Toda and Yamamota causality tests. The findings indicated remittances had significant effect on stock market development. Toda Yamamoto causality test indicated a bi-directional causal relationship. Notably, this study is conducted beyond the context of the emerging African stock markets. Therefore the markets regulations and the other factors influencing foreign financial inflows in these markets are obviously different from the Kenyan market context. This creates the need to test the relationship in the context of the emerging African markets such as the Nairobi Securities Exchange Market.

Githaiga and Kabiru (2014) sought to examine the impact of remittances on financial sector development. 
The study covered 31 countries in the period 1980 - 2012. The data was analyzed using the General Moment Method (GMM). The findings from the study indicated that remittances had a negative adverse effect on domestic private sector credit while remittances effect on bank deposit was statistically insignificant. This study considered effect of remittance on the stock market development. Equally data was analyzed using GMM therefore there is need to consider both the long term and short term effects of remittances on the stock market using a lagged model such as the ARDL model.

\section{Research Methodology}

The study adopted a positivism philosophy and a causal research design. The positivist philosophy is a controlled and structural approach of conducting research that involve identification of a clear research topic, construction of hypotheses and adoption of an appropriate research methodology (Carson et al., 2001). Positivism philosophy was appropriate since the study sought to test the hypothesis that diaspora remittances have a significant effect on stock market development at The Nairobi Securities Exchange using a structured scientific approach that involves identification of a researchable area of study, construction of hypothesis and testing of the hypothesis using suitable methodology. Moreover the positivism philosophy leaves very little room for subjectivity as the findings of the study are independent of the researchers' personal opinion (Brymanes \& Bell, 2011). Moreover, the causal research design was appropriate for this study since the study assumes the existence of a statistically significant causal relationship between diaspora remittance and stock market development at The Nairobi Securities Exchange, Kenya.

The study adopted a census design including all firms listed in the Nairobi securities exchange and involved in the computation of the overall market capitalization, market turnover and NSE All Share index. A census design involves a complete enumeration all the units in a given population during data collection (Saunders et al., 2009). Quarterly time series data for the period 2008-2018 relating to stock market capitalization, market turnover, and NASI and diaspora remittances were obtained from the Capital Markets Authority, Kenyan Central Bank and the political risk international website. The models were then estimated using the hierarchical regression analysis procedure (Mogaka, 2016). According to the hierarchical regression analysis procedure, the direct effects were first estimated using the Modified least Squares model (Newey \& West, 1987). Subsequently, the short run and long run cointergation effects are estimated using the autoregressive distributed lag model (Pesaran \& Shin, 1995; Pesaran et al.,2001).

\section{Correlation Analysis Test Results}

The Karl Pearson correlation matrix is applied to test the relationship between the independent variables and the dependent variables of the study. Table 2 below is a presentation of the findings from correlation analysis.

Table 2: Karl Pearson Correlation Analysis Results

\begin{tabular}{|l|c|c|c|c|}
\hline \multicolumn{1}{|c|}{} & $\operatorname{lnMCAP}$ & $\operatorname{lnMTNR}$ & $\ln$ ASI & InREM \\
\hline LnMCAP & 1 & & & \\
& & & & \\
\hline LnMTNR & $0.875^{*}$ & 1 & & \\
& $(0.000)$ & & & \\
& $0.974^{*}$ & $0.886^{*}$ & & \\
\hline LnNASI & $(0.000)$ & $(0.000)$ & & \\
& $0.851^{*}$ & $0.593^{*}$ & $0.774^{*}$ & \\
\hline LnREM & $(0.000)$ & $(0.000)$ & $(0.000)$ & \\
\hline
\end{tabular}

\section{Source: Study Data (2019)}

Table 2. Above indicates a high positive significant correlation between Diaspora Remittances (REM) and stock market development as measured using market capitalization, market turnover and the NSE All Share index. According to Njoroge (2014), the increased awareness about the returns in the market, has led to increased amounts of remittances investment in the stock market. Unlike other sources of external finance, diaspora remittances are directly sent to the recipient from the sender. Thus tend to be more stable making diaspora remittances a reliable source of financing for developing countries (Ratha \& Mohapatra, 2007).

\section{Cointergration Test Results}

The Autoregressive Distributed Lag (ARDL) bound test proposed by Pesaran and Shin (1999) and Pesaran et 
al.,(2001) was applied by the study to test for the existence long run cointergration. Unlike other methods of cointergration such as Engle and Granger (1987) and the Johansen test (1991), ARDL is appropriate when the variables are intergrated of order I(0) or intergrated of order I(I) but not intergrated of order I(2). Table 3: presents the ARDL Bound Cointergration Test Results with Market Capitalization, Market Turnover and NSE All Share index as the dependent variables.

Table 3: Summary of ARDL Cointergration Test Results

Table 4.30a ARDL-ECM Coefficients (Dependent Variable: Market Capitalization)

\begin{tabular}{|c|c|c|c|c|}
\hline & Short Run C & fficients & Long Run C & fficients \\
\hline Variable & Coefficient & Prob & Coefficient & Prob. \\
\hline $\ln R E M$ & 3.9857 & $0.0032<0.05$ (significant) & 0.7326 & $0.0056<0.05$ (significant) \\
\hline ECT & -0.7203 & $0.0001<0.05$ (significant) & & \\
\hline Table 4.3 & RDL-ECM & efficients (Dependent Va & e: Market T & nover) \\
\hline Variable & Coefficient & Prob & Coefficient & Prob.* \\
\hline $\operatorname{lnREM}$ & 0.8955 & $0.0416<0.05$ (significant) & 3.7697 & $0.0002<0.05$ (significant \\
\hline ECT & -0.6168 & $0.0005<0.05$ (significant) & & \\
\hline Table 4.3 & RDL-ECM & efficients(Dependent Var & : NSE All SI & e Index) \\
\hline Variable & Coefficient & Std. Error & Coefficient & Prob. $*$ \\
\hline $\operatorname{lnREM}$ & 0.9301 & $0.0003<0.05$ (significant) & 0.7076 & $0.0174<0.05$ (significant) \\
\hline ECT & -0.6030 & $0.0006<0.05$ (significant) & & \\
\hline
\end{tabular}

\section{Source: Study Data (2019)}

The coefficient of the Error Correction Term (ECT) indicates the speed at which the model adjusts to long run equilibrium while the sign of the ECT indicates the direction of adjustment to equilibrium (Pesaran et al., 2001). According to Shahbaz et al., (2013) the coefficient of the error correction term should be negative and significant. A highly significant negative coefficient of the error correction term is an indication of stable long run equilibrium of the model (Bannerjee, Dolado \& Mestre,1998). The findings presented on Table 3 above indicates that diaspora remittances have a significant short run effect on market capitalization as a measure of stock market development as evidenced by the negative and significant coefficient of the error correction term. The error correction term has a coefficient of -0.7203 with a 0.0001 probability value less than 0.05 . This implies that model adjusts back to long run equilibrium quarterly at a speed of 72.04 percent. This further demonstrates a long run equilibrium running causality running from diaspora remittances to market capitalization as a measure of stock market development.

Further, Table 3 above indicates that diaspora remittances have a significant effect on market turnover as evidenced by the negative and significant coefficient of the error correction term. The error correction term has a coefficient of -0.6168 with a 0.0005 probability value less than 0.05 . This implies that the system corrects itself back to equilibrium quarterly after a market shock a speed of 61.69 percent. This further demonstrates a long run equilibrium running causality running from diaspora remittances to market turnover as a measure of stock market development. Equally, diaspora remittances have a significant short run effect on the NSE All Share index as a measure of stock market development as evidenced by the negative and significant coefficient of the error correction term. The error correction term has a coefficient of -0.603007 with a 0.0006 probability value less than 0.05. This implies that model adjusts back to long run equilibrium quarterly at a speed of 60.30 percent. Further, confirming that all the variables are cointergrated.

Finally, the findings support the existence of a significant positive long run relationship between diaspora remittance and market capitalization as a measure of stock market development. Diaspora remittance had a coefficient 0.732624 with a P-value of 0.0056 . Since 0.0056 is less than 0.05 the study rejects the null hypothesis and finds that diaspora remittances have a significant long run effect on stock market development as measured using market capitalization. Equally, diaspora remittances had a coefficient of 3.7697 with a P-value of 0.0002 less than 0.05 with market turnover. Hence the null hypothesis is rejected and the study finds that diaspora remittances have a significant positive long run effect on stock market development as measured using market turnover. Moreover, the findings support the existence of a significant positive long run relationship between diaspora remittance and the NSE All Share index as a measure of stock market development. Diaspora remittance had a coefficient 0.7076 with a P-value of 0.0174 . Since 0.0174 is less than 0.05 the study rejects the null hypothesis and finds that diaspora remittances have a significant long run effect on stock market development as measured using the NSE All Share index. These findings are support the findings by Njoroge (2014) indicating that diaspora remittance had strong and significant positive effect on stock market performance in Kenya.

\section{Conclusions, Policy Implications and Recommendations}

In view of the above results the study the study finds that diaspora remittances had a positive and significant long run effect on market capitalization, market turnover and the NSE All Share index as indicators of stock market 
development. Equally, diaspora remittances had a positive and significant short run effect on market capitalization, market turnover and the NSE All Share index as indicators of stock market development. Since diaspora remittances had a significant positive effect on market capitalization, market turnover and the NSE All Share index the study concludes that an increase in diaspora remittances will result in enhanced market value, liquidity and price stability. The study therefore makes the following recommendations in view of the above findings.

First, the Kenyan government thorough the ministry of foreign affairs and other government agencies need to reconsider the Kenya foreign investment policy and the effectiveness of each foreign inflow with the sole objective being to attract productive foreign financial inflows such as diaspora remittances. The foreign investment policy should only target those inflows that have a productive effect on the stock market and other sectors of the economy. More emphasis should be placed on foreign inflows such as diaspora remittances that have a high significant positive effect on stock market development. Secondly, the government needs to devise measures that would boost investor confidence and thus attract increased Diaspora remittances.

The government should institute aggressive campaigns targeting the Kenyans living in the diaspora to educate them on the importance of investing back at home. The Kenya government should create a department of economic relations to be located at all Kenyan foreign embassies abroad. The department will be charged with the role of sensitizing the Kenyans in the diaspora on the available investment opportunities at the Nairobi Securities Exchange. Thirdly, the national assembly therefore needs to provide a conducive environment for diaspora investors through formulation of favorable investment policies, ensuring political stability, minimizing bureaucracy and managing corruption.

\section{REFERENCES}

Adjasi, K. C., and Biekpe, N. (2006). Stock Market Development and Economic Growth: The Case of Selected African Countries," African Development Review, 18 (1):144-161

Amanja D. and Morrisey T. (2005). Foreign Aid, Investment and Economic Growth in Kenya: A Time Series Approach. Centre for Research in Economic Development and International Trade, University of Nottingham.

Bannerjee, A., Dolado, J. and Mestre, R. (1998). "Error Correction Mechanism Tests for Cointegration In Single Equation Framework." Journal of Time Series Analysis 19, 267- 283.

Barnor, C. (2014). The Effect of Macroeconomic Variables on Stock Market Returns in Ghana. Walden university.

Baron, R. M., and Kenny, D. A. (1986). The Moderator-Mediator Variable Distinction in Social Psychological Research: Conceptual, Strategic, and Statistical Considerations. Journal Personality and Social Psychology, 51(6), 1173-11182.

Bayar, Y. (2016). Foreign Capital Inflows and Stock Market Development in Turkey. Springler International Publishing.

Bryman, A., \& Bell, E. (2011). Business Research Methods (3rd Ed.), Oxford: Oxford University Press.

Capital Markets Authority (2017). Statistical Bulletin. Retrieved From www.cma.or.ke.

Carson, D., Gilmore, A., Perry, C., \& Gronhaug, K. (2001). Qualitative Market Research. London: Sage.

Calson, M. (2006). A Brief History of The 1987 Stock Market Crash With a Discussion of The Federal Reserve Response. Finance and Economics Discussion Series. Federal Reserve Board, Washington D.C.

Cooper, R. D., and Schindler, S. P. (2008). Business Research Methods. India: Tata MCP Graw-Hill.

Ender, W. (1995). Applied Econometric Time Series in Probability and Statistics. Wiley and Sons Publishers, New York.

Engle, R.F., Granger, C. (1987). Co-Integration and Error Correction: Representation, Estimation and Testing. Econometrica Pp.251-276.

Enrico, C. and Oijen (2001). Privatization, Political Risk and Stock Market Development in Emerging Economies. Journal of International Money and Finance. 20(1) 43-69.

Githaiga P. and Kabiru C. (2014). Remittances as a Determinant Financial Sector Development Journal of Business, Economics \& Finance 3(4) 2146 - 7943.

Granger, C.J. (1969). Investigating Causal Relationships By Econometrics Models And Cross-Spectral Methods. Econometrica 37(3):424-438.

Greene, W.H. (2008). Econometric Analysis (6th Ed.), Upper Saddle River, New Jersey, USA: Prentice Hall.

Gujarati, D. (2003). Basic Econometrics (4th Ed.), New York, USA: Mcpgraw Hill.

Hacker RS, Hatemi, J.A. (2006). Tests for Causality Between Integrated Variables Using Asymptotic and Bootstrap Distributions: Theory And Application. Journal of Applied Economics. 38(13):1489-1500.

Hadi, A., Hiung, E, Hamad, S. Iqbal, T. (2016). Financial Market Theory of Development: Evidence From Pakistani And Israeli Stock Exchange Markets. Journal of Peryurusan. 46.

Helleiner, E. (2011) Understanding the 2007-2008 Global Financial Crisis Lesson for Scholars of International Political Science. Annual Review of International Political Science 14 67-87.

Hearn, B., and Piesse, J. (2010). Barriers to the Development of Small Stock Markets: A Case Study of Swaziland and Mozambique. Journal of International Development. 22, 1018- 1037. 
Hymer, S.H. (1976). The International Operation of National Firms: A Study of Direct Foreign Investment, MT Press, Cambridge, MA, United States.

Idenyi. S, Ifeyinwa. C, Obinah. J. and Agbi, .P. (2016). Impact of Foreign Direct Investment on Stock Markets Growth in Nigeria. Asian Research Journal of Arts and Social Science 1- 14.

Iwedi, M. \& Igbenibo, D. S. (2015). "Foreign Private Investment and the Development Economies: Evidence from Nigeria”. Developing Countries Studies, 5(19), 53.

IMF (2003). World Economic Outlook: Growth and Institutions. International Monetary System.

IMF (2005). Annual Report: Making The Global Economy Work For All. International Monetary Fund.

Kibaara, B.(2008). The Impact of the Global Financial Crisis on the Developing Countries: Case of Kenya. Available Online at http//www.ios.ac.ke.

Kraemer H, Kazdin A, Sifford D And Kupfer D. (2001). How Do Risk Factors Work Together? Mediator, Moderator, Independent, Overlapping and Proxy Risk Factors. American Journal of Psychiatry. 158(6) 848856

Merton, R. (1987). A Simple Model for Capital Markets Equilbrium with Incomplete Information. Journal of Finance. 42(3): 483-510.

Mills, T. C. (1999). The Econometric Modelling of Financial Time Series, 2nd Edn., Cambridge: Cambridge University Press.

Mogaka, D. (2017). Short-Term Financing Decisions and Financial Performance of Non-Financial Firms Listed at the Nairobi Securities Exchange, Kenya. Phd Thesis, Kenyatta University. Also available online at http://repository.ku.ac.ke

Mungami, E.S. (2013). Determinants Of Lease Financing Decisions By Non-Financial Firms Quoted On Nairobi Securities Exchange, Kenya. Phd Thesis, Kenyatta University.

Mwangi, W. (2014). Effect Of Financing Decisions on The Perfomance of Non-Financial Companies Listed at The Nairobi Securities Exchange Market. Phd Thesis Kenyatta University.

Nairobi Securities Exchange (2016). Annual Reports. Retrieved From https://www.nse.co.ke.

Nairobi Securities Exchange (2018). Quarterly Statistical Bulletin. Retrieved From https://www.nse.co.ke.

Ngugi, R. W. (2003a). Development of the Nairobi Stock Exchange: A Historical Perspective. Kenya Institute for Public Policy Research and Analysis (KIPPRA) Discussion Paper No. 27, Nairobi.

Ngugi, R. W. (2003b). What Defines Liquidity Of The Stock Market? The Case of Nairobi Stock

Exchange. Kenya Institute for Public Policy Research and Analysis (KIPPRA) Discussion Paper No. 29, Nairobi.

Ngugi, R. W., and Njiru, R. (2005). Growth of the Nairobi Stock Exchange Primary Market. Kenya Institute for Public Policy Research and Analysis (KIPPRA) Discussion Paper No. 47, Nairobi.

Ngugi and Nyangoro (2005). Institutional Factors and Foreign Direct Investment Flows: Implication for Kenya. Discussion Series Published By KIPPRA.

Ngugi, R., Amanja, D., \& Maana, I. (2009). Capital Market, Financial Deepening And Economic Growth In Kenya. In Centre for the Study of African Economies Conference, 22-24.

Ngugi, R.W, Amanja, D. and Maana, I. (2010). The Capital Market And Economic Growth Kenya: Policies For Prosperity. Oxford University Press.

Njoroge, W. (2014). Effect of Diaspora Remittance On Stock Market Performance: Evidence From Nairobi Securities Exchange. International Journal of Current Aspects In Finance (IJCAF), 2(2) 1-11.

Nyangoro, (2013). Foreign Portfolio Flows and Stock Market Performance in Kenya: Case of Nairobi Securities Exchange. PHD Thesis, University of Nairobi, CSAE Conference on Economic Development in Africa.

Nwiado, D. and Deekor, L. (2013). The Domestic Bond Market and the Development of the Nigerian Capital Market: An Empirical Analysis. Journal of Economics and Sustainable Development. 4(7).

Oziengbe, S. and Ovuefyen, J. (2013). Foreign Financial Resources Inflow and Stock Market Development; Evidence from Nigeria and Ghana. The Research Journal of Finance and Accounting, 4(9).

Osoro, C. and Jagongo, A. (2014). Investor Perceptive on the NASI and the NSE All Share Index As Performance Measurement Indicators at the Nairobi Securities Exchange. International Journal of Humanities and Social Sciences. 3(18).

Pesaran, M. H, \& Shin, Y. (1999). An Autoregressive Distributed Lag Modeling Approach to

Cointegration Analysis. In Strom S (Ed) Econometrics and Economic Theory in the 20th Century: The Ragnar Frisch Centennial Symposium. Cambridge University Press, Cambridge.

Pesaran, M. H. Shin, Y. \& Smith, R. J. (2000). Structural Analysis of Vector Error Correction Models With Exogenous I(1) Variables. Journal of Econometrics 97(293-343).

Pesaran, M. H. Shin, Y. \& Smith, R. J. (2001). Bounds Testing Approaches to the Analysis of Level Relationships. Journal of Applied Economics, 16 (289-332).

Rajan, R.G. And Zingales, L. (2003). The Great Reversal and the Politics of Financial Development of $20^{\text {th }}$ Century Journal of Financial Economics, 69(1):5-50.

Raza, SA, Jawaid, S..T (2014). Foreign Capital Inflows, Economic Growth and Stock Market Capitalization in 
Asian Countries: An ARDL Bound Testing Approach. Qual Quant 48(1):375-385.

Raza, S.A, Jawaid, S.T., Afshan, S, Karim, M.S.Z. (2015). Is Stock Market Sensitive To Foreign Capital Inflows And Economic Growth? Evidence from Pakistan. Journal of Economic and Foreign Trade 8 (3):142-164.

Raza, A., Iqbal, N., Ahmed, Z., Ahmed, M. and Ahmed, T. (2012). The Role of FDI On Stock Market Development: The Case Of Pakistan. Journal of Economics and Behavioral Studies. 4(1) 26-33.

Raza, S. A., and Jawaid, S. T. (2012). Foreign Capital Inflows, Economic Growth and Stock Market Capitalization in Asian Countries: An ARDL Bound Testing approach, Quality And Quantity, DOI: 10.1007/S11135-0129774-4.

Ratha, D., (2003). Worker's Remittances: An Important and Stable Source of External Development Finance. Global Development Finance, 157-172.

Ratha, D., \& Mohapatra, S., (2007). Increasing the Macroeconomic Impact of Remittances on Development. Development Prospects Group. Washington D.C: World Bank.

Republic of Kenya. (2007). Kenya Vision 2030 - A Globally Competitive and Prosperous Kenya. Nairobi: Government Printer.

Republic of Kenya. (2014). Kenya Foreign Policy Statement 2014. Nairobi. Also available online at www.mfa.go.ke

Republic of Kenya. (2015). Budget Policy Statement 2015. Nairobi. Also available online at www.treasury.go.ke

Republic of Kenya. (2016). Kenya Economic Report 2016. Also available online and Retrieved from http://www.knbs.or.ke// Downloads/Kenya Economic Report 2016.

Republic of Kenya. (2018). Kenya Economic Report 2018. Also available online and Retrieved http://www.knbs.or.ke //Downloads/Kenya Economic Report 2018.Pdf

Saunders M, Lewis P. and Thornhill, A. (2009). Research Methods For Business Studies Fifth Ed Pearson Educational Centre Edinburgh Gate, Harlow, And Essex CM 202 England.

Shahbaz, M. Qureshi, M. N. \& Naveed, A. (2007). Remittances and Financial Sector's Performance: Under Two Alternative Approaches for Pakistan. International Research Journal of Finance and Economics. Issue 12.

World Bank (2018). International Financial Markets Statistics. Http://Data Worldbank.Org/Indicator

Vargas, S. and Huang, P. (2006). "Macroeconomic Determinants of Workers' Remittances: Host Versus Home Country's Economic Conditions." Journal of International Trade and Economic Development 15(1) 81-99.

Yartey, A. C. (2008) The Determinants of Stock Market Development In Emerging Economies: Is South Africa Different? IMF Working Paper No. WP/08/32, Washington D.C.: International Monetary Fund.

Yartey CA (2010). The Institutional and Macroeconomic Determinants of Stock Market Development in Emerging Economies. Journal of Applied Finance and Economics, 20(21):1615-1625. 